УДК $94(497.11+497.16) \ll 19 / 20 »$

DOI: https://doi.org/10.33782/eminak2019.2(26).299

\title{
СЕРБО-ХОРВАТСЬКІ ВІДНОСИНИ У 90-Х рр. XX - ХХІ ст.
}

\author{
Ігор Власюк \\ Житомирський державний університет імені Івана Франка (Житомир, Україна) \\ e-mail: vlasyuk@zu.edu.ua \\ ORCID: https://orcid.org/0000-0003-4679-4101
}

У статті розкрито стан і проблеми розвитку сербо-хорватських відносин на сучасному етапі, з урахуванням їхнього історичного минулого. Проаналізовано причини та наслідки загострення цих відносин у 90-х рр. ХХ ст. Виділено позитивні кроки щодо нормалізації відносин між двома народами у ХХІ $\mathrm{cm}$.

Ключові слова: серби, хорвати, відносини, війна, геноцид, $\epsilon C$

Проблеми сербо-хорватських відносин на сучасному етапі залишаються актуальною темою для історичних досліджень. Необхідно зазначити, що в українській історичній науці вони є малодослідженими та потребують подальшого грунтовного осмислення, особливо у XXI ст. Зокрема, розвиток цих відносин переважно у 1990-х рр. проаналізовано у низці досліджень українських і зарубіжних істориків, серед яких необ-

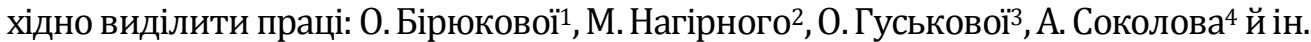

Метою статті $\epsilon$ комплексне дослідження головних тенденцій і проблем сербохорватських відносин у 90-х рр. XX - XXI ст.; спроба відповіді на складні, суперечливі питання взаємин між цими двома південнослов'янськими народами, з урахуванням їх історичного минулого.

Завданнями дослідження $\epsilon$ аналіз історичного минулого сербів і хорватів у попередні епохи; виявлення динаміки розвитку сербо-хорватських відносин у 90-х рр. XX XXI ст., зв'язку їх із зовнішніми чинниками (зокрема, євроінтеграційними процесами); виділення причин загострення цих відносин на сучасному етапі; аналіз кроків щодо нормалізації відносин між двома народами у XXI ст.

Відмінності розвитку сербів і хорватів виявлялися ще 3 періоду середньовіччя. Аналізуючи ці процеси, важливо зазначити, що:

1) між сербськими та хорватськими племенами існувала боротьба за територію та впливи ще з VII ст., періоду заселення ними Балканського півострова; 2) хорвати від-

\footnotetext{
1 Бірюкова 0.О. Сучасні Балкани: внутрішньополітичні проблеми та зовнішньополітичні перспективи // Вісник Харківського національного університету імені В.Н. Каразіна. Сер. «Питання політології». 2009. № 861, Вип. 15. С. 218-227.

2 Гуськова Е. Независимая Хорватия с независимыми сербами // Югославия в XX веке: Очерки политической истории / Отв. ред. К.В. Никифоров. Москва: «Индрик», 2011. С. 775-804; Гуськова Е.Ю. История югославского кризиса (1990-2000). Москва: Русское право / Русский национальный фонд, 2001. 720 с.

${ }^{3}$ Нагірний М. Хорватсько-сербська війна: уроки для України // Наукові записки Тернопільського національного педагогічного університету імені Володимира Гнатюка. Сер. Історія. Тернопіль: Тернопільський національний педагогічний університет імені Володимира Гнатюка, 2015. Вип. 1, Ч. 2. С. 207-210.

4 Соколов А.В. Процессы нормализации отношений между бывшими республиками СФРЮ на современном этапе (внешние и внутренние факторы): автореф... канд. ист. наук: 07.00.03. Москва, 2008. $33 \mathrm{c}$.
} 
чули більший місіонерський вплив на своїх землях з боку Римської курії християнської церкви; у той час як серби перебували під геополітичним і духовним впливом 3 боку Візантійської імперії та Східної церкви; 3) державотворчі процеси на хорватських землях привели до створення своєї першої незалежної держави у Х ст.; сербські племена тривалий час ворогували між собою до другої половини XII ст., коли було об'єднано їх під владою династії Неманичів (1165-1367); 4) хорватські феодали ще в епоху королівства в XI ст. заявили про себе як про важливу політичну силу в державі, зберігаючи свій вплив навіть в умовах перебування під владою угорських королів; сербський клас феодалів сформувався, на думку Ф. Дворніка, досить пізно і тому не міг до XIV ст. суттєво впливати на обмеження влади сербських правителів5; намісники часів Стефана Душана (1331-1355) заявили про свої сепаратистські настрої лише після його смерті; 5) хорвати у Новий час відчули великий вплив з боку європейських держав, перебуваючи під владою династії Габсбургів; вони змогли зберегти свої традиційні державні інститути, маючи свій парламент (Сабор) і місцевого правителя (бана); серби ж боролися за національне визволення з Османською імперією, їх прагнення набули більше визвольних та об'єднавчих ідей при відновленні державності; 6) важливо також відмітити, що хорвати у складі Угорського королівства продовжували перебувати у рідному для них релігійному середовищі (римо-католицькій вірі), тоді як серби на чолі з Печським патріархатом Сербської православної церкви постійно боролися проти поневолення, принижень та утисків з боку турків; 7) хорвати у 1918 р. практично готові були у сприятливий момент закінчення Першої світової війни до об'єднання під своєю владою частини південних слов'ян; їхні автономістські погляди значно розходилися з ідеями сербів, які тяжіли до унітаризму, монархічного правління. Періоди перебування хорватів у складі міжвоєнного королівства Югославії, часів правління Тіто (1945-1980) виявили практично різне бачення шляхів розвитку державності (діяльність хорватських депутатів у парламенті Королівства сербів, хорватів і словенців; події «Хорватської весни» 1971 р. тощо) ${ }^{6}$.

Тому станом на початок 1990-х рр. Хорватія, до того ж як одна з найрозвинутіших економічно республік СФРЮ, була готова до відокремлення та прагнула цього. Перемога на виборах 1990 р. Християнської демократичної співдружності на чолі з Франьо Туджманом у Хорватії, на думку Д. Гайдая, пояснювалася прагненнями хорватського суспільства до змін у політичній та економічній сферах, посилювалася обіцянками їх побудувати заможну, незалежну та європейську державу. 3 іншого боку, це призвело до міжнаціонального протистояння та міжетнічного поділу політичних партій (так, Сербська народна партія представляла інтереси сербів у Хорватії). В Сербії у цей час правляча верхівка посилювала націоналістичні настрої, побоювання втрати державності та національних прав сербів; виразником їх стала Соціалістична партія Сербії на чолі із Слободаном Мілошевичем7.

Проблема геноциду сербів, а також хорватів періоду Другої світової війни $\epsilon$

\footnotetext{
5 Дворнік Ф. Слов’яни в Європейській історії та цивілізації / Пер. з англ. Київ: Дух і літера, 2000 // Ізборник. URL: http://litopys.org.ua/dvornik/dv.htm

6 Чиркович С.М. История сербов; Пер. с сербскохорв. Москва: Изд-во «Весь мир», 2009. 448 с.; Фрейдзон В.И. История Хорватии. Краткий очерк с древнейших времен до образования республики (1991 г.). Санкт-Петербург: Алетейя, 2001. 318 с.

7 Гайдай Д.Ю. Формування партійних систем Хорватії, Сербії, Боснії і Герцеговини // Актуальні проблеми політики: зб. наук. пр. / С.В. Ківалов (голов. ред.). Одеса: Фенікс, 2012. Вип. 46. С. 261262.
} 
окремою трагічною сторінкою, ранами на тілі обох народів, які продовжують нагадувати про себе і сьогодні.

Відомо, що 10 квітня 1941 р. було створено Незалежну Хорватську державу, під керівництвом керівника усташів Анте Павелича. Моноетнічна ідеологія усташського режиму зробила головними ворогами Хорватії сербів, євреїв і циган. Злочинні факти геноциду цього режиму проти названих народів на хорватській території (знищено понад півмільйона сербів; при цьому застосовувались жахливі методи тортур над в'язнями концтаборів; відбувалося насильне перехрещення сербів у римокатолицьку віру). Кількість загиблих сербів у концтаборі Ясеновац у різних оцінках становить від 280 тис. до 700 тис. осіб. На міжнародній історико-богословській конференції «Православно-католицький діалог після Ясеноваца» (28жовтня 2010 р., Санкт-Петербург), за результатами багатьох досліджень, кількість загиблих у концтаборі Ясеновац-Доня Градина була названа у 700 тис. ні в чому не винних чоловіків, жінок і дітей, серед яких було 500 тис. сербів, 40 тис. циган, 33 тис. євреїв 8 .

3 іншого боку, хорвати свідчили про факти геноциду щодо їхнього народу з боку сербських партизан. Незважаючи на ці трагічні події в історії обох народів, спільна боротьба проти німецько-нацистського окупаційного режиму на території Югославії змогла об'єднала частину хорватів із сербами у національно-визвольній армії під керівництвом Й. Броз Тіто.

Напруженість у відносинах між двома країнами з приводу трагічного минулого сербів часів Другої світової війни продовжує зберігатись. Так, 22 липня 2016 р. суд Загреба скасував вирок і повністю реабілітував одного хорватського кардинала, якого було засуджено судом Югославї до позбавлення волі та 16 років примусових робіт і на 5 років позбавлення усіх громадянських і політичних прав за пособництво нацистам у роки Другої світової війни. Це рішення суду викликало негативну реакцію та різкі висловлювання з боку влади Сербії, що призвело до ноти протесту з боку Хорватії. У ній йшлося про нетерпимість сербської влади, неприйняття нею європейських цінностей і втручання у внутрішні справи суверенної держави з боку Белграду. Однак, МЗС Сербії негайно відреагував зустрічним документом, в якому розцінив дану справу як реабілітацію Незалежної держави Хорватії та фашизму. Як було зазначено, Сербія виступає за добросусідські відносини та примирення, але ніхто не повинен принижувати Сербію і жертв усташського терору9.

У липні 2018 р., виступаючи в Ясеноваці, Президент Хорватії К. Грабар-Кітарович висловила глибоку скорботу за всіма жертвами Голокосту в Хорватії та колабораціоністського режиму усташів періоду Другої світової війни, який приніс жахливі страждання єврейській громаді, а також сербам, циганам і хорватам, а також всім тим, хто вважався ворогам режиму того часу. Вона також, у черговий раз, засудила будь-який тоталітарний режим, нацизм, фашизм, комунізм і підкреслила, що освіта $€$ найпотужнішою зброєю проти усіх форм радикальної ідеології, поділу, ненависті та расизму. 3 іншого боку, Президент Хорватії рішуче засудила і маніпуляції з кількістю жертв голокосту в концентраційному таборі Ясеновац, що не засновані на історичних фактах і використовуються у політичних цілях або для нав'язування колек-

\footnotetext{
8 Брдар С., Брдар С. Концентрационный лагерь Ясеновац (1941-1945). Доклад на международной историко-богословской конференции «Православно-католический диалог после Ясеноваца» // Православие.ru. 06.12.2010. URL: http://www.pravoslavie.ru/43279.html

9 Сербия и Хорватия обменялись нотами протеста // Senica.ru. 28.07.2016. URL: http://www.senica.ru/serbia/news/serbiya-i-khorvatiya-obmenyalis-notami-protesta
} 
тивної провини Хорватії та хорватському народу, оскільки багато хорватів тоді виступали проти режиму усташів, віддаючи життя за свободу та людяність ${ }^{10}$.

Глибинними причинами сербо-хорватського конфлікту у Хорватії на початку 1990-х рр. окремі дослідники називають різне ставлення сербів і хорватів до існування СФРЮ. У відповідь на дії представників Сербської автономної області у 1991 р. було застосовано акти перевірки сербів на лояльність хорватській владі, арешти та переслідування їх ${ }^{11}$.

Як зазначає О. Бірюкова, напруженість між двома країнами зберігалася у 90-х рр. XX ст. у зв'язку зі становищем сербів у Хорватії, які нерідко змінювали національність, прізвища, приймали католицизм; сербський націоналізм посилювався і через звільнення з роботи через етнічну приналежність ${ }^{12}$.

У 1992-1994 рр. на сербо-хорватські відносини впливала внутрішньополітична ситуація у Хорватії та Союзній Республіці Югославії, а також події громадянської війни в Боснії і Герцеговині.

Війна у Хорватії (1991-1995) мала трагічні підсумки: взаємні етнічні чистки сербського та хорватського населення; загибель понад 30 тис. людей; півмільйона стали біженцями; знищувалися міста та села; негативні наслідки для економіки Хорватії (понад 30 млрд. дол. прямих збитків) ${ }^{13}$.

Сьогодні часто проводяться паралелі між вирішенням проблеми сепаратизму у Хорватії в 1995 р. та подіями в Україні на Донбасі. Олександр Левченко, посол України в Хорватії та Боснії і Герцеговині у 2010-2017 рр., вважає, що у ключовому питанні український і хорватський сценарії надто відрізняються тим, що, зокрема, жодна політична сила в Хорватії не виступала за від'єднання сепаратистських територій. На його думку, хорватський досвід також вчить, що завжди $є$ негідники, які на війні та людських стражданнях заробляють великі гроші. Конфлікт у Хорватії, підкреслює він, мав виразні ознаки міжнаціонального та міжрелігійного зіткнення (сербів 3 хорватами, православних з католиками), а на Донбасі протистояння $\epsilon$ більше світоглядного характеру, без чіткого поділу за релігійною чи національною ознакою14.

На початку XXI ст. сербо-хорватські відносини, на відміну від 1990-х рр., розвивались більше з позитивними тенденціями, хоча й досить складно. Важливим чинником цього процесу були зміни у владних відносинах у Союзній Республіці Югославії (прихід до влади В.Коштуніци у вересні 2000 р., арешт колишнього союзного президента С. Мілошевича; перехідний етап до остаточного розлучення Сербії та Чорногорії у 2002-2006 pр.). Однак, у цих відносинах продовжувало тяжіти історичне минуле обох народів, зокрема, пам'ять про масові вбивства сербів у незалежній державі Хорватії в роки Другої світової війни, події 1990-х рр. на території самопроголошеної Сербської Країни у Хорватії, геноцид сербів проти хорватів у минулому й ін.; вагому роль відігравав протягом усього XX ст. і релігійний чинник.

10 Сербы возмущены: Колинда в Ясеноваце говорила о хорватских жертвах и «сербской агрессии»! // Senica.ru. 26.07.2018. URL: http://www.senica.ru/balkans/news/serby-vozmushchenykolinda-v-yasenovace-govorila-o-khorvatskikh-zhertvakh-i-serbskoy-agressii

11 Васильева Н., Гаврилов В. Балканский тупик? Историческая судьба Югославии в XX веке. Москва: Гея итэрум, 2000. С. 328, 332.

12 Бірюкова 0.О. Сучасні Балкани... С. 223.

13 Гуськова Е. Независимая Хорватия с независимыми сербами... С. 800.

14 Левченко О. Чому Хорватії вдалося: як країна повернула території після років окупації та гібридної війни // Європейська правда. Міжнародна безпека та євроінтеграція України. 4.08.2017. URL: ttps://www.eurointegration.com.ua/articles/2017/08/4/7069423/ 
На початку XXI ст. відбувається активізація економічних, політичних і культурних відносин між двома країнами, на відміну від конфліктного періоду 1990-х рр. 3 іншого боку, продовжують існувати територіальні суперечки (про розмежування півострова Превлаки, Которської затоки, проблема з подунайським кордоном між Сербією та Хорватією); також серйозною є проблема повернення сербських біженців на територію Хорватії15.

Відомо також, що ще у липні 1999 р. Хорватія подала заяву до Міжнародного суду ООН, звинувачуючи Союзну республіку Югославія у порушенні Конвенції ООН про попередження злочину геноциду та покарання за нього. Судовий процес за взаємними звинуваченнями Сербії і Хорватії у геноциді тривав більше 15 років, й у лютому 2015 р. Міжнародний суд ООН прийняв рішення відмовити обом сторонам у задоволенні їхніх позовів. Було визнано, що Сербія і Хорватія у ході міжетнічних війн 1990-х рр. здійснювали серйозні злочини, але відповідно до Конвенції ООН, вони не можуть кваліфікуватися як геноцид ${ }^{16}$.

Необхідно відзначити певні позитивні кроки з боку президентів Хорватії Степана Месича (2000-2010рр.), Іво Йосиповича (2010-2015 рр.), Колінди Грабар-Кітарович (з 2015 р.) щодо нормалізації відносин із Сербією.

Під час візиту у вересні 2003 р. президента Хорватії С. Месича до Сербії глави обох держав вибачилися перед хорватським і сербським народами за вчинені злочини у минулому, що було першим взаємним публічним вибаченням. Такий крок став новою сторінкою сербо-хорватських відносин. На думку окремих журналістів, про налагодження цих добрих взаємних стосунків треба більше говорити у засобах масової інформації, оскільки у сербів і хорватів ще залишилися сліди ворожнечі17.

3 іншого боку, різні підходи до вирішення внутрішньо- та зовнішньополітичних питань, пам'ять про міжетнічну війну 1990-х рр. продовжували вносити негативні тенденції у розвиток двосторонніх відносин. Так, у 2010 р. президент Хорватії С. Месич закликав усі країни світової спільноти визнати незалежність Косово, тому що це стало новою реальністю. Необхідно зазначити, що С. Месич відвідав Приштину після оголошення незалежності Косово ще у лютому 2008 р. Зближенню позицій Хорватії та Косово сприяли євроінтеграційний шлях і боротьба за незалежність; також війна у республіках Югославії 1991-1995 рр., під час якої, за деякими даними, добровольці з цього краю воювали у складі хорватських збройних сил. Такі дії хорватського президента викликали різку критику з боку президента Сербії Бориса Тадича. Сербія, як відомо, не визнає незалежність Косова, вважаючи край своєю територією18.

Різними були відносини Сербії та Хорватії і з боснійськими сербами. Зокрема, у жовтні 2009 р. Степан Месич заявив, що прем'єр-міністр Республіки Сербської у Боснії і Герцеговині Мілорад Додік намагається розвалити країну, звинувативши його

\footnotetext{
15 Соколов А.В. Процессы нормализации отношений между бывшими республиками СФРЮ на современном этапе (внешние и внутренние факторы)... С. 27.

16 Международный суд ООН отверг взаимные обвинения Сербии и Хорватии в геноциде // Новости 00Н. 03.02.2015. URL: https://news.un.org/ru/audio/2015/02/1026571

17 Варга Б. Президенти Сербії і Хорватії вибачилися // BBC. 11.09.2003. URL: https://www.bbc.com/ukrainian/news/story/2003/09/030911_croatia_serbia.shtml

18 Президент Хорватії С. Месич закликав світову спільноту визнати незалежність Косова // РБКУкраїна. 09.01.2010.

URL: https://www.rbc.ua/ukr/news/prezident_horvatii_s_mesich_prizval_mirovoe_soobshchestvo_priznat_n ezavisimost_kosova_09012010
} 
у продовженні політики екс-президента Югославії Слободана Мілошевича, тільки іншим способом. Відомо, що тодішній лідер Союзної Республіки Югославії Слободан Мілошевич надавав у ході громадянської війни в цій республіці підтримку армії боснійських сербів. Одним з найкривавіших епізодів війни вважалося взяття боснійськими сербами міста Сребрениця влітку 1995 р. Белград, на думку хорватського президента, проводить нещиру політику щодо Боснії і Герцеговини, підтримуючи варіант розвалу країни. Зі свого боку М. Додік відповів на цю заяву звинуваченням С. Месича у продовженні ясеновацької політики щодо боснійських сербів, закликав його перестати турбуватися про них і зосередити увагу на боснійських хорватах ${ }^{19}$.

Важливим кроком у подальшій нормалізації сербо-хорватських відносин був дводенний візит хорватського президента Іво Йосиповича у жовтні 2013 р. до Белграду. Плідною стала заява обох президентів про те, що Сербія і Хорватія не забувають минулого, але й дивляться у майбутнє; основою їхнього співробітництва має бути взаємна довіра та відкритий діалог. Президент Сербії Томислав Ніколич вважав за необхідне скасували взаємні позови за звинуваченнями у геноциді, які обидві країни подали до Міжнародного суду, що краще було б врегулювати шляхом договору та поступок. Хорватського лідера турбувала, насамперед, доля близько тисячі хорватів і семисот сербів, які безвісти пропали під час воєнних дій у першій половині 1990-х років. Також відкритими були питання щодо прав сербської меншини у Хорватії (бл. 200 тис. осіб) і хорватської меншини у Сербії (60 тис. осіб)20.

Історичним моментом у сучасних сербо-хорватських відносинах стало підписання у червні 2016 р. в сербському місті Суботиця, де проживає значна кількість етнічних хорватів, «Декларації про розвиток відносин і вирішення відкритих питань Сербії і Хорватії». У ній містяться важливі пункти щодо захисту прав нацменшин в обох країнах (сербів і хорватів); кордону на спірних ділянках; пошуку зниклих громадян обох республік у ході збройних конфліктів у колишній Югославії; про спільну боротьбу з міжнародним тероризмом і міграційною кризою; про взаємодію Белграда та Загреба у спільних проектах і проектах $€ \mathrm{C}^{21}$.

Процес нормалізації відносин між Сербією та Хорватією був пов'язаний значною мірою із пріоритетними завданнями обох країн на шляху демократизації, вступу до НАТО та ЄС. Хорватія з 2013 р. $є$ повноправним членом $Є$, тоді як Сербія продовжує бути кандидатом на вступ до цього союзу. Різняться позиції обох країн і в інших міжнародних питаннях. Так, у питаннях відносин з Російською Федерацією та санкцій проти неї, проблемі незалежності Косово позиція Хорватії співпадає з офіційними рішеннями $Є С$, тоді як Сербія не бажає приєднуватись до цих санкцій, а в другому питанні лише визнає де-факто становище, що склалося у цьому регіоні, не змирившись із втратою цієї території22.

К. Грабар-Кітарович заявила у 2015 р., що Сербії необхідно ввести санкції проти Росії, яка порушує міжнародне право. Говорячи про особливу дружбу та відносини

\footnotetext{
19 Глава Хорватии и боснийские сербы обменялись жесткими обвинениями // Известия. 26.11.2009. URL: https://iz.ru/news/462607

20 Рамач М. Сербія і Хорватія можуть відмовитися від позовів за звинуваченнями у геноциді // Радіо Свобода. 17.10.2013. URL: https://www.radiosvoboda.org/a/25140240.html

${ }^{21}$ Сербия и Хорватия подписали договор о развитии отношений // Senica.ru. 21.06.2016. URL: http://www.senica.ru/serbia/news/serbiya-i-khorvatiya-podpisali-dogovor-o-razvitii-otnosheniy ${ }^{22}$ Сербія хоче в $Є С$, але ніколи не введе санкції проти Росії - глава МЗС // Європейська правда. Міжнародна безпека та євроінтеграція України. 13.11.2017. URL: https://www.eurointegration.com.ua/news/2017/11/13/7073558/
} 
між Сербією та Росією, вона зазначила, що це нормально, однак у момент, коли увесь Європейський Союз і сучасний світ вводить режим санкцій щодо Росії, Сербії необхідно збалансувати свою позицію таким чином, щоб поважалися міжнародні санкції, тому що вони не введені без причини. Росія, за її словами, порушила міжнародний правовий порядок XXI ст., російське керівництво має повернутися на шлях поваги та підтримки міжнародних відносин ${ }^{23}$.

У лютому 2018 р. прем'єр-міністр Хорватії Андрій Пленкович зазначив про необхідність вирішення питань військових злочинів, захисту меншин, долі зниклих без вести, меж і репарації; тільки після цього Белград і Загреб можуть досягти примирення та почати співпрацювати у рамках ЄС. Низка двосторонніх питань між двома країнами, особливо проблема долі зниклих без вісті під час конфлікту 1990-х років у колишній Югославії, як вважає президент Хорватії К. Грабар-Кітарович, ускладнюють процес приєднання Сербії до Євросоюзу, і їй будуть потрібні роки для того, щоб виконати умови розділів 23 і 24 відповідного договору. Ці питання, підкреслила вона, необхідно вирішити незалежно від європейської інтеграції Сербії, тому їх можуть вирішити тільки Хорватія і Сербія; потрібен діалог двох сторін. Між Хорватією та Сербією станом на 2019 р. існує низка відкритих протиріч, серед яких - проблеми демаркації кордону та статусу національних меншин. Євросоюз виділяє пріоритетним питання врегулювання відносин між Белградом і Приштиною (Косово) ${ }^{24}$.

Отже, розвиток сербо-хорватських відносин був складним, особливо трагічним у 1990-х рр., через самопроголошення Республіки Сербської Країни та збройні конфлікти на території Хорватії. Обидві сторони набули досвіду вирішення цих складних проблем, однак занадто високою ціною людських жертв і міграцій сотень тисяч громадян, великих збитків для економіки. На початку XXI ст. ці відносини набули певних позитивних тенденцій, що значною мірою пов'язано з євроінтеграційними процесами в обох республіках, намаганням примиритись обом країнам і вирішити серйозні проблеми останніх двох десятиліть. Однак напруженість і складність у відносинах між двома країнами продовжує зберігатись (через пам'ять про історичне минуле, у т.ч. події 1991-1995 рр.; релігійний чинник; різні позиції у низці міжнародних проблем). Різні аспекти цих відносин (зокрема, економічні та релігійні) потребують подальшого грунтовного вивчення.

\section{REFERENCES}

Biriukova, 0.0. (2009). Suchasni Balkany: vnutrishnopolitychni problemy ta zovnishnopolitychni perspektyvy [Modern Balkans: the domestic politics and foreign policy perspectives]. Visnyk Kharkivskoho natsionalnoho universytetu im. V. N. Karazina. Ser. Pytannia politolohii, 861, 15, 218-227 [in Ukrainian].

Brdar, S., Brdar, S. (2010). Kontsentratsionnyi lager Yasenovats 1941-1945 [The concentration camp Jasenovac (1941-1945)]. Doklad na mezhdunarodnoi istoriko-bogoslovskoi konferentsii Pravoslavno-katolicheskii dialog posle Iasenovatsa Retrieved from http: www.pravoslavie.ru.43279.html [in Russian].

Chirkovich, S.M. (2009). Istoriia serbov [Serbian history]. Moskva: Izd-vo Ves mir [in Russian].

Dvornik, F. (2000). Sloviany v Yevropeiskii istorii ta tsyvilizatsii [The slavs in European history and civilization]. Kyiv: Dukh i litera. Retrieved from http://litopys.org.ua/dvornik/dv.htm [in Ukrainian].

23 Президент Хорватии: Сербия должна ввести санкции против России // Senica.ru. 22.01.2015. URL: https://www.senica.ru/balkans/news/prezident-khorvatii-serbiya-dolzhna-vvesti-sankcii-protivrossii

${ }^{24}$ Хорватия не хочет пускать Сербию в EC // Eadaily.com. 28.01.2019. URL: https://eadaily.com/ru/news/2019/01/28/horvatiya-ne-hochet-puskat-serbiyu-v-es. 
Guskova, E. (2011). Nezavisimaia Khorvatiia s nezavisimymi serbami [The independent Croatia with the independent serbs]. In Yugoslaviia v XX veke: Ocherki politicheskoi istorii (pp. 775-804). Moskva: Indrik [in Russian].

Guskova, E.Yu. (2001). Istoriia yugoslavskogo krizisa. 1990-2000 [The history of the yugoslav crisis (1990-2000).]. Moskva: Russkoe pravo Russkii natsionalnyi fond [in Russian].

Haidai, D.Yu. (2012). Formuvannia partiinykh system Khorvatii, Serbii, Bosnii i Hertsehovyny [The formation of the party systems in Croatia, Serbia, Bosnia and Herzegovina]. Aktualni problemy polityky: zbirnyk naukovyh prats, 46, 261-262 [in Ukrainian].

Levchenko, 0. (2017). Chomu Khorvatii vdalosia: yak kraina povernula terytorii pislia rokiv okupatsii ta hibrydnoi viiny [Why did Croatia succeed: how the country returned the territories after the years of $\begin{array}{llll}\text { occupation and hybrid } & \text { wetrieved } & \text { from }\end{array}$ https://www.eurointegration.com.ua/articles/2017/08/4/7069423 [in Ukrainian].

Nahirnyi, M. (2015). Khorvatsko-serbska viina: uroky dlia Ukrainy [The croatian-serbian war: the experience for Ukraine]. Naukovi zapysky Ternopilskoho natsionalnoho pedahohichnoho universytetu imeni Volodymyra Hnatiuka. Seriia Istoriia, 1 (2), 207-210 [in Ukrainian].

Sokolov, A.V. (2008). Protsessy normalizatsii otnoshenii mezhdu byvshimi respublikami SFRIU na sovremennom etape: vneshnie i vnutrennie factory [The processes of normalization of the relations between the former republics of the SFRY at the present stage (the external and internal factors)]. (Extended abstract of Candidate's thesis). Moskva [in Russian].

Vasileva, N., Gavrilov, V. (2000). Balkanskii tupik? Istoricheskaia sudba Yugoslavii v XX veke [Balkan deadlock? The historical fate of Yugoslavia in XX century]. Moskva: Geia iterum [in Russian].

Freidzon, V.I. (2001). Istoriia Khorvatii. Kratkii ocherk s drevneishikh vremen do obrazovaniia respubliki (1991 g.) [The history of Croatia. Brief essay from antiquity to the formation of republic (1991)]. $\mathrm{SPb}$.: Aleteiia [in Russian].

\section{Igor Vlasyuk}

(Zhytomyr Ivan Franko State University, Zhytomyr, Ukraine)

ORCID: http://orcid.org/0000-0003-4679-4101

\section{Serbia-Croatia Relations in the 90 s of the $20^{\text {th }}-21^{\text {st }}$ century}

The state and problems of Serbia-Croatia relations development at the present stage, taking into account their historical past, are disclosed in the paper.

The reasons and consequences of the aggravation of those relations in the $90 \mathrm{~s}$ of the $20^{\text {th }}$ century are analyzed, among them: the different attitude of the Serbs and Croats to the existence of the SFRY; state-building processes in Croatia during the collapse of Yugoslavia; the intensification of Croatian and Serbian nationalism, etc.

Positive steps taken to normalize relations between the two peoples in the twenty-first century are pointed out, and in both republics, they are mainly connected with European integration processes, an attempt of both states to reconcile and to solve the serious problems of the last two decades.

The positions of Croatia in a number of international issues coincide with the official decisions of the EU (recognition of Kosovo, sanctions against the Russian Federation, etc.), while Serbia does not support such decisions. A few bilateral issues of relations with Croatia, requiring a serious bipartite dialogue, complicate the process of Serbia's joining the EU.

The tension and difficulties between the two countries can be observed even now (due to the remembrances of Serbian genocide during the Second World War, the events of 19911995, the religious factor, and the unresolved problems of the last two decades).

Keywords: Serbs, Croats, relations, war, genocide, EU 